\title{
Practices, Opportunities, and Challenges Of SIP in Primary Schools of Ilu Gelan Woreda, West Shoa Zone, Oromia Regional State
}

\author{
Etecha Fekadu Dabesa ${ }^{1}$, Shireye Fekadu Cheramlak ${ }^{2}$ \\ ${ }^{1}$ Department of Educational Planning and Management, College of Education and Behavioral \\ Studies, Wolkite University, Wolkite, Ethiopia \\ 2 Department of Educational Planning and Management, College of Education and Behavioral \\ Studies, Wolkite University, Wolkite, Ethiopia
}

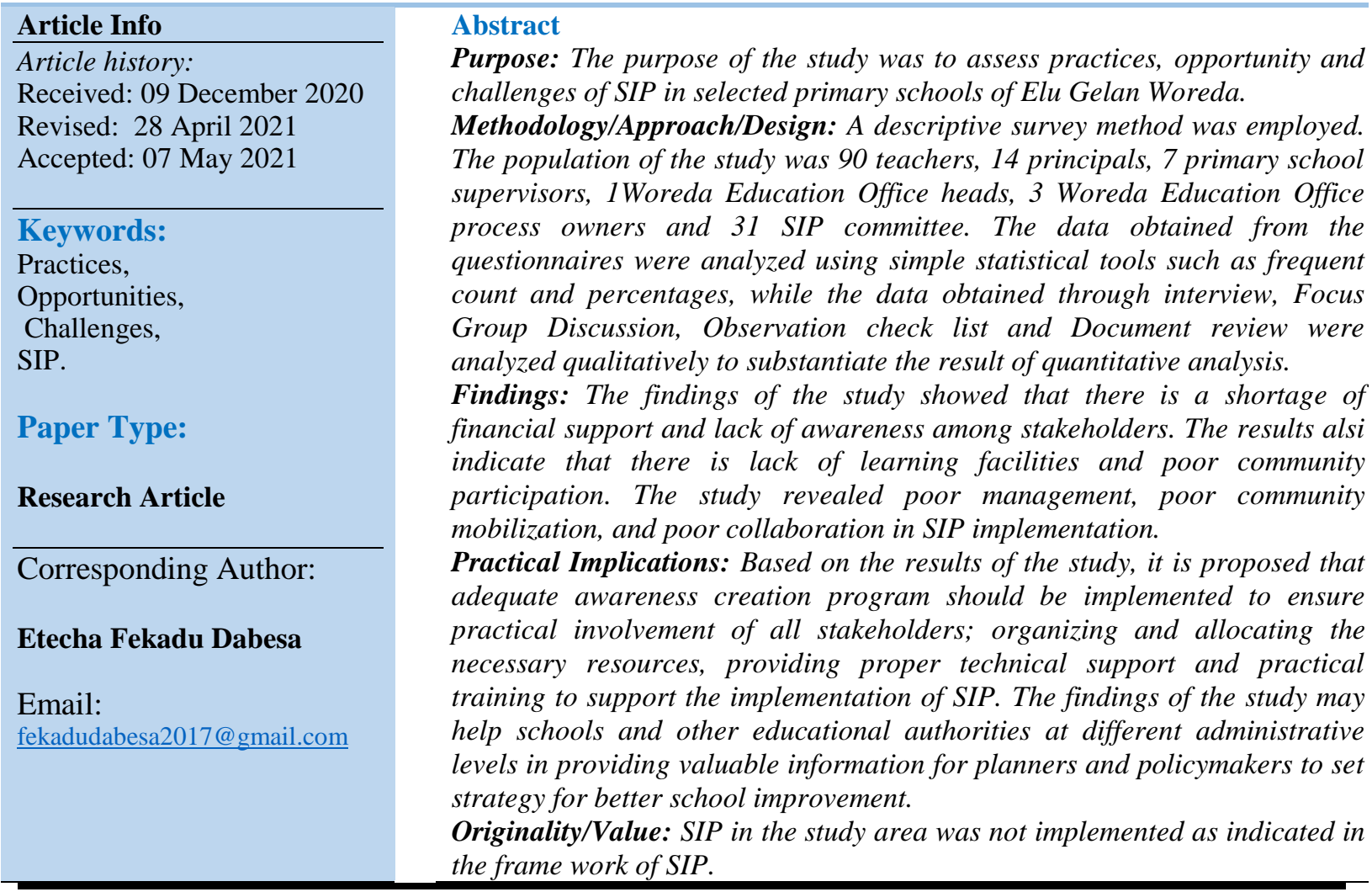

\section{Introduction}

Education is considered the foremost and fundamental element in all social needs and priorities all over the world (Anees, 2001). A nation promotes its self-consciousness by sensitizing (motivating) its citizens through education-social institution that provide training for educating and developing their citizens mentally, physical, ideologically, and morally (Anees, 2001). Stoll and Fink (1996) suggested that school improvement should be the activity of each school In line with this, Barnes (2004), has confirmed that even the highest ranked schools will always need improvement because the condition under which learning 
environment of the children always need change and improvement. School improvement is defined in international school improvement project as systematic, sustained effort aimed at change in learning conditions in one or more schools, with ultimate aim of accomplishing educational goals more effectively (Hopkins,1989). According to plan international (2004), school improvement means making schools better places for learning. This relies on changes at both school level and with classroom, which depends on schools be committed to fulfilling the expectations of children and their parents.

In this context school improvement refers to a systematic approach that improves the quality of schools and hence the quality of education. According to Hopkins (1989), SIP is a plan of initiated education program based on successful experience of improving quality of education which has to follow an approach of collaborative responsibility and shared achievement. Similarly, Epstein (1997) considers school improvement program as a road map that sets out the changes a school needs to make improve the level of student achievement and shows how and when this change is made.

SIP is one of the basic tools for the development of any country. On a global scale of the current educational climate, SIP initiative becomes a focus of attention and the dominant approach to educational change for enhancing quality of student achievement and attainment as well as strengthening school internal capacity for change (Hopkins, 2001, p.19). SIP is the outstanding strategy to ensure quality education in schools by bringing paradigm effective changes. Recently quality education has attracted considerable attention and become a critical issue for many countries in the world. For this reason, many countries have begun to undertake different initiative to produce education to their students. As an example Australia is conducting the school excellence initiative (SEI) to improve the quality of education and to achieve high learning outcome (ACT, 2004).

The SIP encourages staff and parents to monitor students achievements and other factors such as environment, that are known to influences student success with up-to-date and reliable information about how students are performing, school are better able to respond to needs of students ,teachers and parents. The desire of all parents is to have quality functional education programs for their children from the nursery school to the university level (Ojo, 2008). This is an indication of quality education that the society needs for their children. Recently, the MoE has launched general education quality improvement package (GEQIP) which comprises six programs.

The SIP is one of the GEQIP elements among others. GEQIP design is based on findings from school effectiveness research. The school effectiveness approach is particularly suitable for GEQIP given the particular and fiscally decentralized structure of the Ethiopian education system, and in which quality improvement will depend on the capacity of school leadership to work with teachers, parents and students to diagnose constrain and implement change to improve results. One of the most important challenges of GEQIP is ability to integrate all the various components of the program which increased the completion rates and secondary school entrance (UNICEF, 2009). 
The current Ethiopian government's commitment in expansion of general education seems encouraging. However, the number of schools and enrolment rates do not indicate the progress of the education sector. There is a need to ensure quality, equality, and efficiency (internal and external efficiency). This situation necessitates carrying out an investigation of the recently introduced SIP in terms of the domains, and selected indicators set out for implementation in selected primary schools of Ilu Gelan Woreda, West Shoa Zone.

Education indicators are tools for the planning, monitoring and evaluating the development of the education system and they help to understand how well the sector performs. Quality is one major indicator of an education system that requires improvement of SIP introduced to enhance the quality of the general education sector. Research in education at different corner of the country is also as important as the pressing need for expanding educational opportunities and for improving the quality at all levels as well as, for planning, implementing, monitoring and evaluating the performance of education system. The Ethiopia Education and Training Policy (ETP) April 1994 also pointed out research in education as one of its specific objectives (MoE, 1994).

The Ethiopian Government's commitments and efforts to improve the access, quality and efficiency of the countries education system since, the adaption of the policy in 1994, it was observed the major achievement of the policy was in access, implying that much has to be done to improve the quality. The Ethiopian Federal Ministry of Education (MoE) has currently become aware of the problems that hinder the provision of quality education and has become cognizant of the importance of launching the SIP. The Ethiopian SIP was introduced in 1999 E.C. as one component of six pillars identified for the general education quality improvement package (GEQIP), when a new program is introduced it may face many challenges in its implementation since SIP is also a new program under implementation, we cannot say that it is being implemented perfectly. Even if we assume that it is being implemented perfectly, an assessment of the achievements, challenges and prospects is essential. Above all, SIP is a dynamic process that involves many stakeholders and resources as its input, process, output, outcome, and impact which need to be realized through scientific investigations.

Thus, in order to ensure the effective and efficient implementation of the program, it is necessary to identify its strengths, weakness, threats and opportunities through research; and then to propose possible scenarios of retaining the achievements, for correcting the weaknesses /challenges for preventing possible threats and for harvesting the opportunities. On top of this, many related studies have been conducted on SIP implementation in Ethiopian context. Dereje Hafosha (2012), Habtamu (2014) and Rahel Ashagre (2014) were the recent one. Dereje (2012), examined the status of implementation and challenges of SIP in Government secondary schools of Oromia Special Zone Surrounding Finfine and his finding indicated that the extent of teachers, students and parents participation in planning and 
implementation of SIP was low, the mechanism through which monitoring and evaluation practice to support SIP implementation was not in position to effectively run SIP.

In 2014, Habtamu's study was conducted to assess the implementation of SIP in selected secondary schools of West Wollega Zone. His finding indicated that the majority of leaders were not qualified in the position they hold currently, shortage of financial resource, lack of learning facility, poor community participation in implementation of SIP. In her study, Rahel Ashagre (2014) concluded that the shortage of facilities, lack of commitment from teachers to create conducive environment, lack of giving attention to teaching and learning create low awareness of SIP implementation. However, in Ilu Gelan Woreda this kind of research has not taken place at any level of schools. Therefore, the recognition of major practices, opportunities and challenges of SIP in the selected schools are important in finding timely solutions for developing and improving SIP.

\section{Methodology and Procedures}

\section{Population, Samples size and Sampling Techniques}

The target population of the study was primary school teachers, principals, supervisors Woreda Education Office head, Woreda Education Office process Owners and SIP Committees. In this Woreda there were 31 government primary schools. Among these schools seven $(22 \%)$ of them namely: Ejaji and Gora were selected from town schools and Baro, Elala, Jato, Lelistu and Saden Elu were selected from rural kebeles'. The rationale behind selecting these seven primary schools is that there are seven clusters in this Woreda. Four-five primary schools were included under each cluster. Therefore, for this research purpose one primary school from each cluster were randomly selected by using simple random sampling technique. Because the researcher use simple random sampling to measure variables distributed in a population. Additionally, schools were selected by this technique was also represent indifferent clustered schools at different location with variety of background and experiences through the Woreda.

Table 1: Sample size and population of the study

\begin{tabular}{|c|c|c|c|c|c|c|c|c|c|c|c|c|}
\hline $\mathrm{NO}$ & Schoo & \multicolumn{5}{|c|}{ Population } & \multicolumn{5}{|c|}{ Sample } & Sampling Techniques \\
\hline & & 总 & 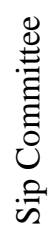 & 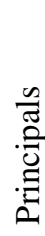 & 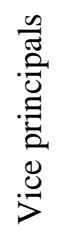 & 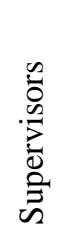 & 岕 & 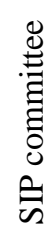 & 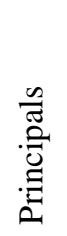 & 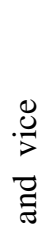 & 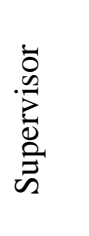 & \\
\hline 1 & Baro & 28 & 11 & 2 & & 1 & 10 & 5 & 2 & & 1 & Simple Random Sampling \\
\hline 2 & Ejaji & 56 & 10 & 2 & & 1 & 20 & 4 & 2 & & 1 & Simple Random Sampling \\
\hline 3 & Elala & 43 & 9 & 2 & & 1 & 15 & 4 & 2 & & 1 & Simple Random Sampling \\
\hline 4 & Gora & 37 & 10 & 2 & & 1 & 14 & 4 & 2 & & 1 & Simple Random Sampling \\
\hline 5 & $\begin{array}{l}\text { Lelistu } \\
\text { Gotera }\end{array}$ & 28 & 11 & 2 & & 1 & 10 & 5 & 2 & & 1 & $\begin{array}{l}\text { Simple Random Sampling } \\
\text { Random } \\
\text { Sampling }\end{array}$ \\
\hline
\end{tabular}




\begin{tabular}{|l|l|l|l|l|l|l|l|l|l|l|}
\hline 6 & $\begin{array}{l}\text { Seden } \\
\text { Elu }\end{array}$ & 29 & 9 & 2 & 1 & 11 & 4 & 2 & 1 & $\begin{array}{l}\text { Simple } \\
\text { Random } \\
\text { Sampling }\end{array}$ \\
\hline 7 & Jato & 31 & 11 & 2 & 1 & 11 & 5 & 2 & 1 & $\begin{array}{l}\text { Simple } \\
\text { Random Sampling }\end{array}$ \\
\hline & Total & 252 & 71 & 14 & 7 & 90 & 31 & 14 & 7 & \\
\hline
\end{tabular}

\section{Data Collection Instrument}

To secure reliable and adequate information, selecting of appropriate data collecting instrument is essential. Therefore, this study mainly employed questionnaires, interview, focus group discussion, and observation checklists.

Questionnaires: A questionnaires is an enquiry of data gathering provided or respond to statements in writing and used to get factual information (Best and Kahan, 2005), so the researcher used questionnaires for similar cases. This study used questionnaires for teachers and school principals. The questionnaires consisted of 11 open ended and 41 closed ended items which are basically aimed at exploring the implementation of SIP. The close ended items were formulated in five-point likertscale (strongly disagree $=1$, Disagree $=2$, Undecided=3, Agree=4, and strongly agree=5) and open ended items were provided for the respondents to freely express their ideas. The questionnaires had two categories: the respondents' personal characteristics and items relevant to the SIP.

Interview: Interview gives the needed information face to face. Moreover, interview is important to find out what is in someone else's mind (Best \&khan, 2005). Gubrium and Holstein (2001) also stated that interview is useful instrument to generate often important and crucial information. Thus, with this assumption interview is used as data gathering instrument and semi-structured interview was prepared on issues related to the practices, opportunities and challenges on implementing SIP. The interview questions were prepared in English and translated to Oromo Language for more clarity of concept for respondents. The interview was conducted with 1Woreda Education Office heads, 3 Woreda Education Office process owners and 7 supervisors.

Focus Group Discussion (FGD): Focus group discussion has special importance to the study. It is suitable to gather qualitative data that goes one-step further than interview. For this study, it was appropriate to generate group discussion from community and students who are members of (SIC) team. Because it is believed that making discussion among individuals (more than two) may provoke more ideas to argue and allow the researcher to gain more refined data. The relevant points of the discussions were taken by writing on notebook in order to minimize loss of information. Four-Five participants participated in the FGD. This tool is used to explore the level of stake holder's awareness on SIP, practices, opportunities and challenges. 
Observation checklist: Observation was made to check the availability of learning environment, school documents and learning facilities. The intention was made to get factual information about real classroom teaching and learning process as well as physical environment of the school such as building, class room, facilities and educational materials.

\section{Methods of Data Analysis}

The quantitative data gathered through questionnaires from teachers and school principals were analyzed by using simple statistics such as percentage, frequency counts and tables. Qualitative data which is gathered from teachers and principals through, open-ended questions, interviews from primary schools Supervisors, woreda Education Office heads, process owners and focus group discussion from SIC members and document review and observation were summarized by grouping respondent's ideas and qualitatively described by words in the interpretation of data.

\section{Results and Discussion}

One hundred four (104) copies of the questionnaire were distributed for the purpose of the study, of which $90(86.5 \%)$ were for teachers, 14(13.5\%) were for school principals. Among the distributed questionnaire $7(6.7 \%)$ questionnaires were not returned from teachers. Then from the total questionnaires distributed, 97(93.2\%) copies of questionnaires were collected, rated and analyzed statistically. Interview was conducted with 1Woreda Education Office head, 3 WEO process owners and 7primary school supervisors. Focus group discussion was conducted with 31 SIP committee members in each sample school of the study area.

\section{The Practices of SIP with respect to school Domain}

School improvement is about change i.e., driven by commitment to increase the learning outcomes of every student. As indicated in (MoE, 2011, p.5) document, the aims of SIP are achieving student's achievement, creating accountability and responsibilities in school management and decentralizing leadership and management in schools. In order to achieve these objectives, the program in corporate four school domain: teaching and learning, learning environment, school leadership and management and community participation. Each domain consist of three elements a total of twelve elements that are focused on different essentials that can influence student result and learning outcomes (MoE, 2011:6). So for elaboration let us see them one by one.

\section{Learning and Teaching Domain}

Teaching and learning is vital instrument of education to bring about desire change in students. The school improvement research base highlights the centrality of teaching and learning in the pursuit of sustained school improvement (Hopkins et al., 1994) in teaching learning process, the teacher, the learner the curriculum and other variables are organized in systematic way to attain same pre-determined goals. 
Table-2: Responses of Principals on the four domains of teaching and learning.

\begin{tabular}{|c|c|c|c|c|c|}
\hline & \multirow[t]{3}{*}{ Scales } & \multicolumn{4}{|c|}{ Respondents } \\
\hline & & \multicolumn{2}{|r|}{ Principals } & \multicolumn{2}{|c|}{ Teachers } \\
\hline & & No & $\%$ & No & $\%$ \\
\hline \multirow{5}{*}{$\begin{array}{l}\text { Students'classroom participation (as } \\
\text { student centered) teaching method is } \\
\text { employed by teachers. }\end{array}$} & Strongly Disagree & - & - & - & - \\
\hline & Disagree & 2 & 14.2 & 11 & 13.2 \\
\hline & Undecided & 5 & 25 & 13 & 15.6 \\
\hline & Agree & 7 & 50 & 45 & 54.2 \\
\hline & Strongly agree & - & - & 14 & 16.8 \\
\hline \multirow{5}{*}{$\begin{array}{l}\text { Arrangements of tutorial programs } \\
\text { for female and slow learner }\end{array}$} & Strong Disagree & - & - & - & - \\
\hline & Disagree & 2 & 14.2 & 3 & 3.6 \\
\hline & Undecided & 4 & 28.5 & 9 & 10.8 \\
\hline & Agree & 8 & 57.1 & 60 & 72.2 \\
\hline & Strong Agree & - & - & 11 & 13.2 \\
\hline \multirow{5}{*}{$\begin{array}{l}\text { Active participation of students in } \\
\text { school clubs. }\end{array}$} & Strongly Disagree & 6 & 42.8 & 27 & 32.5 \\
\hline & Disagree & 8 & 57.2 & 56 & 67.4 \\
\hline & Undecided & 5 & 35.7 & 15 & 18 \\
\hline & Agree & 6 & 42.8 & 52 & 62.6 \\
\hline & Strong Agree & - & - & - & \\
\hline \multirow{5}{*}{$\begin{array}{l}\text { Evaluation of curriculum has been } \\
\text { made by teachers }\end{array}$} & Strongly Disagree & - & - & - & - \\
\hline & Disagree & 2 & 14.2 & 20 & 24 \\
\hline & Undecided & 4 & 28.5 & 19 & 22.8 \\
\hline & Agree & 8 & 57 & 27 & 32.5 \\
\hline & Strongly Agree & - & - & 17 & 20.4 \\
\hline \multirow{5}{*}{$\begin{array}{l}\text { Action research conducted by } \\
\text { teachers }\end{array}$} & Strongly Disagree & - & - & - & - \\
\hline & Disagree & 5 & 35 & 20 & 24 \\
\hline & Undecided & 4 & 28.5 & 25 & 30.1 \\
\hline & Agree & 5 & 35.7 & 21 & 25.3 \\
\hline & Strong Agree & - & - & 17 & 20.4 \\
\hline \multirow{5}{*}{$\begin{array}{l}\text { The school implement continuous } \\
\text { assessment }\end{array}$} & Strong Disagree & - & - & - & - \\
\hline & Disagree & - & - & - & - \\
\hline & Undecided & 5 & 35.7 & 20 & 24 \\
\hline & Agree & 9 & 64.3 & 45 & 54.2 \\
\hline & Strongly Agree & & - & 8 & 9.6 \\
\hline \multirow{5}{*}{$\begin{array}{l}\text { The availability of functional } \\
\text { laboratories practical teaching and } \\
\text { learning process }\end{array}$} & Strongly Disagree & 6 & 42.8 & 27 & 32.5 \\
\hline & disagree & 8 & 57.2 & 56 & 67.4 \\
\hline & undecided & - & - & - & - \\
\hline & Agree & - & - & - & - \\
\hline & Strong Agree & - & - & - & - \\
\hline \multirow{5}{*}{ Availability of instructional media. } & Strongly Disagree & - & - & - & - \\
\hline & Disagree & 8 & 57.2 & 51 & 61.4 \\
\hline & Undecided & 3 & 21.5 & 22 & 26.5 \\
\hline & Agree & 3 & 21.5 & 10 & 12 \\
\hline & Strongly Agree & - & - & - & - \\
\hline
\end{tabular}


As shown in table 2, respondents were asked to indicate their agreement on the extent to which students' classroom participation(student-centered) teaching method employed by teachers, $7(50 \%)$ of principals agree,5(25\%)of principals respondents undecided while $2(14.2 \%)$ of principal respondent disagree.14(16.8\%)of teacher respondents strongly agree on which students' classroom participation(student-centered)of teaching method employed by teachers. $45(54.2 \%)$ of teachers agreed,13(15.6\%) of teacher respondents undecided,11(13.2\%) of teacher respondent disagree. The majority of respondents agreed on issue that student centered teaching method employed by teachers. In line with this (Erickson, 1984) suggest that students are not empty vessels; they come to class with their own perceptual frame works and learn in different ways (kolb, 1984). In short, students content their own meaning by talking, listening, writing, reading and reflecting on context ideas, issues and concern, (MeyersandJones,1991).In student-centered environments, learners are given direct access to the knowledge-based and work individually and in small groups to solve authentic problems.

Concerning item 2 of table2, respondents were requested to rate the degree to which the tutorial program is arranged for female and slow learners,2(14.2\%)principals respondents disagreed, 4(28.5\%)principals respondents undecided. The majority of principals $8(57.1 \%)$ agreed on issue that tutorial program arranged, 11(13.2\%) of teacher respondents strongly agree, $60(72.2 \%)$ of teacher respondents were agreed, 9(10.8\%)of teacher respondents undecided $8(3.6 \%)$ of them disagree on the issue.

Concerning item 3 of table 2, respondents were requested to the degree to which students are active participation in school club, 6(42.8\%) school principals agreed on the idea that students participate in school clubs and 5(35.7\%) school principals not decided. Only $3(21.4 \%)$ principals disagree on the issue, $16(19.2 \%)$ of teachers disagreed on the idea that students participate in school clubs and 15(18\%) of them are not decided, 52(62.6\%) of them are agreed on the issue.

In line with UNICEF (2010) suggests that children do not develop their capacity solely by being taught in schools. They should be member of different school clubs that provide a forum where students, teachers and other members of the community could share experience, identify problems, and jointly decide and act towards the fulfilment of children's rights. As shown in the table2, respondents where requested to rate the degree to which the curriculum has been made by teachers, $8(57 \%)$ principal respondents agreed on evaluation of curriculum has been made by teachers and $4(28.5 \%)$ of principal respondents have not decided and $2(14.2 \%)$ of principal respondents have disagreed on the issue, 20(24\%) of teachers respondents disagreed on evaluation of curriculum has been made by teachers and $19(22.8 \%)$ of teacher respondents have not decided and 27(32.5\%) of them are agreed on the issue,17(20.4\%) teacher respondents strongly agreed on the evaluation of curriculum has been made by teacher.

In item5 of table 2, the data revealed that 5(35.7) principals agreed on conducting an action research by teachers, 4 (28.5\%) principal respondents have not decided and 5(35\%)of principals respondents disagreed on the issue, 17(20.4\%) of teacher respondents strongly 
agreed on conducting an action research by teachers,21(25.3\%)of teacher respondents were agreed,25(30.1\%)of them have not decided and 20(24\%) disagreed on the issue. The table showed that the majority of Principal and teachers respondents unsatisfactory. In addition, the data gathered from interview, observation and document revised also confirmed that teachers are not willing to do action research to solve educational problem in their schools.

As it has been shown in item 6 of table 2, 9(64.3\%) of principal respondents agreed on continuous had been given by teachers and $5(35.7 \%)$ of principal respondent have not decided, $8(9.6 \%)$ of teachers respondents strongly agreed on continuous had been given by teachers, $45(54.2 \%)$ of teacher respondents were agreed, 20(24\%) of teacher respondents not decided. Teachers and Principal respondents reported their agreement respectively that continuous assessment is being implemented. Therefore, it concluded that, primary school teachers are effective in using continuous assessment. In line with this Harris, 1996(as cited in BEN-E, 2010) reflect that ongoing assessment of student performance can provide teachers with the information they need to improve student learning. The data in item 7 of table2, 6 (42.8) of principal respondents strong disagreed, 8(57.2\%) principal respondents disagreed on using laboratory practical teaching and learning process. $27(32.5 \%)$ of teacher respondents strongly disagreed, 56(67.4\%) of teacher respondents disagreed on using laboratory practical teaching and learning process.

Concerning item 8 table 2, 3(21.5\%) of school principal respondents agreed on availability of instructional media to motivate student learning,3(21.5\%)of school principal respondents have not decided,8(57.2\%) of school principal respondents disagreed on the issue, $51(61.4 \%)$ of teacher respondents disagreed on availability of instructional media to motivate student learning, 10(12\%) of respondents agree,22(26.2\%)have not decided. From the majority of teachers respondents and interviews result it is safe to suppose that schools in Ilu Gelan Woreda did not devote enough attention to apply practical work in the laboratory and use instructional media to improve teaching and learning activities. Therefore, as information gathered from questionnaire, interview, FGD and document observation we conclude that there is low commitment of teacher in conducting action research, curriculum evaluation and use of laboratory and instructional media to motivate student learning.

In this regarded, the MoE (2011) stated that teachers are the main actor among the stake holders in the improvement of schools and growing student outcome. They are expected to use participatory teaching methods, initiate students to have active role in laboratories, integrate student and the curriculum and give class work, homework, individual or group project work to their students.

\section{Learning Environment Domain}

The learning environment domain describes the promotion of positive and respectful relationships which are stable, inclusive. In safe and productive learning environments students willingly engage and participate in the broad range of learning opportunities. According to Harris (2002), the success of any school improvement effort will ultimately depend on the context in which it takes place. 
Table-3: Responses of principals and teachers on learning environment domain

\begin{tabular}{|c|c|c|c|c|c|c|}
\hline \multirow{3}{*}{ Items } & \multicolumn{6}{|c|}{ Respondents } \\
\hline & \multirow{2}{*}{\multicolumn{2}{|c|}{ Principals }} & & & Tea & \\
\hline & & & No & $\%$ & No & $\%$ \\
\hline \multirow{5}{*}{$\begin{array}{l}\text { Appropriate physical environment } \\
\text { (safe, stable and positive } \\
\text { atmosphere in school compound) } \\
\text { for teaching and learning process. }\end{array}$} & \multicolumn{2}{|c|}{ Strong Disagree } & - & - & - & - \\
\hline & \multicolumn{2}{|c|}{ Disagree } & 3 & 21.4 & 13 & 15.6 \\
\hline & \multicolumn{2}{|c|}{ Undecided } & 6 & 42.8 & 20 & 24 \\
\hline & \multicolumn{2}{|l|}{ Agree } & 5 & 35.7 & 39 & 46.9 \\
\hline & \multicolumn{2}{|c|}{ Strong Agree } & - & - & 12 & 14.4 \\
\hline \multirow{5}{*}{$\begin{array}{l}\text { Clear rules and policies of the } \\
\text { school that are communicated by } \\
\text { the school community. }\end{array}$} & \multicolumn{2}{|c|}{ Strong Disagree } & - & - & 4 & 4.8 \\
\hline & \multicolumn{2}{|c|}{ Disagree } & 2 & 7.1 & 21 & 25.3 \\
\hline & \multicolumn{2}{|c|}{ Undecided } & 6 & 42.8 & 13 & 15.6 \\
\hline & \multicolumn{2}{|l|}{ Agree } & 6 & 42.8 & 41 & 49.4 \\
\hline & \multicolumn{2}{|c|}{ Strong Agree } & - & - & 4 & 4.8 \\
\hline \multirow{10}{*}{$\begin{array}{l}\text { Adequate teaching and learning } \\
\text { materials } \\
\text { (e.g. Text books, teachers guides) }\end{array}$} & \multirow[t]{5}{*}{ Book } & $\begin{array}{l}\text { Strong } \\
\text { Disagree }\end{array}$ & - & - & 2 & 2.4 \\
\hline & & Disagree & - & - & 9 & 10.8 \\
\hline & & Undecided & 4 & 28.5 & 8 & 9.6 \\
\hline & & Agree & 10 & 71.4 & 36 & 43.4 \\
\hline & & $\begin{array}{l}\text { Strong } \\
\text { Agree }\end{array}$ & - & - & 28 & 33.7 \\
\hline & \multirow[t]{5}{*}{ Guide } & S. Disagree & - & - & - & - \\
\hline & & Disagree & 3 & 21.4 & 21 & 25.3 \\
\hline & & Undecided & 4 & 28.5 & 20 & 24 \\
\hline & & Agree & 7 & 50 & 32 & 38.5 \\
\hline & & $\begin{array}{l}\text { Strong } \\
\text { Agree }\end{array}$ & - & - & 10 & 12 \\
\hline \multirow{5}{*}{$\begin{array}{l}\text { School community has access to } \\
\text { standard toilets particularly } \\
\text { designated for females and male } \\
\text { students with water. }\end{array}$} & \multicolumn{2}{|c|}{ Strong Disagree } & - & - & 15 & 18 \\
\hline & \multicolumn{2}{|c|}{ Disagree } & 7 & 50 & 32 & 38.5 \\
\hline & \multicolumn{2}{|c|}{ Undecided } & 5 & 35.7 & 14 & 16.8 \\
\hline & \multicolumn{2}{|c|}{ Agree } & 2 & 14.2 & 20 & 24 \\
\hline & \multicolumn{2}{|c|}{ Strong Agree } & - & - & - & - \\
\hline \multirow{5}{*}{$\begin{array}{l}\text { Health relationship among school } \\
\text { community, }\end{array}$} & \multicolumn{2}{|c|}{ Strong Disagree } & - & - & 15 & 18 \\
\hline & \multicolumn{2}{|c|}{ Disagree } & 4 & 28.5 & 24 & 28.9 \\
\hline & Undeci & & 3 & 21.4 & 18 & 21.6 \\
\hline & Agree & & 7 & 50 & 18 & 21.6 \\
\hline & Strong & & - & - & 8 & 9.6 \\
\hline The school has library with recent & Strong & gree & - & - & 20 & 24 \\
\hline reference materials. & Disagr & & 8 & 57 & 42 & 50.6 \\
\hline & Undeci & & 2 & 14.4 & 13 & 15.6 \\
\hline & Agree & & 3 & 21.4 & 9 & 10.8 \\
\hline & Strong & & - & - & - & - \\
\hline
\end{tabular}

Strongly agree $=5$, Agree $=4$, undecided $=3$, Disagree $=2$, strongly disagree $=1$

In item 1 of table 3,5(35.7\%) of principal respondent agreed on the existence of safe and stable learning environment in the sample primary schools,3(21.4\%) of them disagree and,6(42.8\%) have not decided.Whereas, $12(14.4 \%)$ of teacher respondents strongly agree, $39(46.9 \%)$ of teacher respondents agreed on the issue, 13(15.6\%)of them disagree and 20(24\%) not decided on the issue. In line with this, Estyn (2001) suggests that health school 
environment for teaching and learning reflect confidence, trust and mutual respect for cooperation between staff, students, government, parents and wide community is essential for purposeful effort and achievement.

As shown item 2 of table 3, 6(42.8\%) of school principals respondents agreed on the clear rules and policies of school that are communicated by the school community, 2(7.1\%) of them disagreed on that the school had clear rule and policies and communicated in school community and $6(42.8 \%)$ of them have not decided. Whereas $4(4.8 \%)$ of teacher respondents strongly agree, 41(49.4\%)of them agree, 21 (25.3\%)of them disagree and 4(4.8\%) strongly disagree and 13(15.6\%) of them not decided on the issue. Thus, it is possible to conclude that there are clear rules and policies of the school that are communicated by the school community satisfied principals and teachers respondents.

Concerning item 3 of table 3, 10(71.4\%) of school principal respondents agree on the adequacy of teaching and learning materials (student books),4(28.5\%) of them have not decided.28(33.7\%) of teacher respondents strongly agree on the issue,36(43.4\%)of them agreed,9(10.8\%) of them disagree, $2(2.4 \%)$ of them strongly disagree, $8(9.6 \%)$ of them have not decided. Therefore, it is possible to conclude that there are adequate teaching and learning material (text books) were satisfactory. Item 4 of table 3, 2(14.2\%) of school principal respondents agree on the issue, $7(50 \%)$ of them respondents disagreed on school community has access to standard toilets particularly designed for female and male students, 5(35\%) have not decided, 20(24\%) of teacher respondents agree, 32(38.5\%) of them disagree, $15(18 \%)$ strongly disagree, 14(16.8\%) have not decided. Therefore, it is possible to conclude that school community has access to standard toilets particularly designed for female and male students were unsatisfactory.

Item 5 of table $3,7(50 \%)$ of school principal respondents agreed on health relation among principals, teachers, students and other staff members,4(28.5\%) of them disagreed,3(21.4\%) of them have not decided,15(18\%)of teacher respondents strongly disagree,24(28\%) of teacher respondents disagree 18(21.6\%)of them agree, on existence of health relation among student and staff members,8(9.6\%)of teacher respondents strongly agree,18(21.6\%)have not decided on the issue.

Item 6 of table 3:3(21.4\%) of school principal respondents agreed on schools has library with sufficient reference books, $8(57 \%)$ of respondents disagreed on the existence of library with Sufficient reference books and 2(14.2\%) not decided. The table shows that $9(10.8 \%)$ of teacher respondents agreed 13(15.6\%) of teacher respondent have not decided on the issue,42(50.6\%)of teacher respondents disagreed and 20(24\%)teacher respondents have strongly agree.

Furthermore, the data collected through from primary supervisor, observation, FGD conducted with SIC member and open ended questions from teacher showed less moderate learning environment to implement the desired objectives school improvement program of sample area. However, many of the FGD and teacher respondents in all sample schools suggested that there was a shortage of library and up-to date reference books. On other hand 
positive relationship among the communities was poor. In consolidating this idea, Jonson et al. (2005) suggested that success full schools are once with favourable conditions for learning, parent interest in knowledge of schools and positive relationship between principals, teachers and students.

\section{Leadership and management domain}

According to MoE (2011), it is expected of school leaders and management to bring sustainable improvement in schools. This implies leaders are responsible and accountable for the problems and failure of SIP implementation and it is expected of them to find solutions for the identified problems and to adapt good practices for the success of the area under investigation.

\section{Data obtained from principals}

Table, 4: Responses of principals on leadership and management domain.

\begin{tabular}{|c|c|c|c|c|c|}
\hline \multirow{3}{*}{ Items } & \multirow[t]{3}{*}{ Scales } & \multicolumn{4}{|c|}{ Respondents } \\
\hline & & \multicolumn{2}{|c|}{ Principals } & \multicolumn{2}{|c|}{ Teachers } \\
\hline & & No & $\%$ & No & $\%$ \\
\hline \multirow{5}{*}{$\begin{array}{l}\text { Shared vision, Mission, Objectives } \\
\text { and goals to improve student learning }\end{array}$} & Strongly Disagree & - & - & - & - \\
\hline & Disagree & - & - & 21 & 25.3 \\
\hline & Undecided & - & - & 18 & 21.6 \\
\hline & Agree & 10 & 71.4 & 35 & 42.1 \\
\hline & Strongly Agree & 4 & 28.5 & 9 & 10.8 \\
\hline \multirow{5}{*}{$\begin{array}{l}\text { School management commitment for } \\
\text { high student achievement }\end{array}$} & Strongly Disagree & 0 & 0 & - & - \\
\hline & Disagree & 4 & 28.5 & 30 & 36.1 \\
\hline & Undecided & 5 & 35.7 & 25 & 30.1 \\
\hline & Agree & 5 & 35.7 & 28 & 33.7 \\
\hline & Strongly Agree & - & - & - & - \\
\hline \multirow{5}{*}{$\begin{array}{l}\text { Consistency in implementation of } \\
\text { school activities }\end{array}$} & Strongly Disagree & - & - & - & - \\
\hline & Disagree & - & - & 28 & 33.7 \\
\hline & Undecided & 3 & 21.4 & 21 & 25.3 \\
\hline & Agree & 8 & 57.1 & 29 & 34.9 \\
\hline & Strongly Agree & 3 & 21.4 & 5 & 6 \\
\hline \multirow{5}{*}{$\begin{array}{l}\text { High mobilization of community for } \\
\text { SIP support }\end{array}$} & Strongly Disagree & - & - & 10 & 12 \\
\hline & Disagree & 7 & 50 & 20 & 24 \\
\hline & Undecided & 3 & 21.4 & 23 & 27.7 \\
\hline & Agree & 4 & 28.5 & 20 & 24 \\
\hline & Strong Agree & - & - & 10 & 12 \\
\hline \multirow{5}{*}{$\begin{array}{l}\text { The school has created effective } \\
\text { regular communication with all stake } \\
\text { holders. }\end{array}$} & Strong Disagree & - & - & - & - \\
\hline & Disagree & 3 & 21.4 & 36 & 43.3 \\
\hline & Undecided & 6 & 42.8 & 22 & 26.5 \\
\hline & Agree & 5 & 35.7 & 19 & 22.8 \\
\hline & Strong Agree & - & - & 6 & 7.2 \\
\hline \multirow{3}{*}{$\begin{array}{l}\text { Instructional supervisors carry out } \\
\text { classroom supervision }\end{array}$} & Strong Disagree & - & - & 9 & 10.8 \\
\hline & Disagree & 6 & 42.8 & 27 & 32.5 \\
\hline & Undecided & 4 & 28.5 & 26 & 31.3 \\
\hline
\end{tabular}




\begin{tabular}{|c|c|c|c|c|c|c|}
\hline & Agree & 4 & 28.5 & 21 & 25.3 \\
\hline & & Strong Agree & - & - & - & - \\
\hline \multirow{10}{*}{$\begin{array}{l}\text { Continuous follow up, and } \\
\text { support } \\
\text { of student learning }\end{array}$} & \multirow{5}{*}{$\begin{array}{l}\text { Follow } \\
\text { up }\end{array}$} & Strong Disagree & - & - & - & - \\
\hline & & Disagree & 3 & 21.4 & 10 & 12 \\
\hline & & Undecided & - & - & 27 & 32.5 \\
\hline & & Agree & 11 & 78.5 & 38 & 45.7 \\
\hline & & Strong Agree & - & - & 8 & 9.6 \\
\hline & \multirow[t]{5}{*}{ Support } & Strong Disagree & - & - & - & - \\
\hline & & Disagree & 3 & 21.4 & 10 & 12 \\
\hline & & Undecided & - & - & 20 & 24 \\
\hline & & Agree & 11 & 78.5 & 43 & 51.8 \\
\hline & & Strong Agree & - & - & 10 & 12 \\
\hline
\end{tabular}

Strongly agree $=5$, Agree $=4$, undecided $=3$, Disagree $=2$, strongly disagree $=1$

In response to Item 1of table 4, respondents were requested to rate the degree to which shared vision, mission, objectives and goals to improve student learning,10(71.4\%) of principal respondents agreed on there is a shared vision, mission, objectives and goals to improve student learning,4(25.8\%)of principal strong agreed on the issue,9(10.8\%)of teacher respondents strongly agree,35(42.1\%)of teacher respondents were agreed,21(25.3\%)of teacher respondents disagreed,18(21.6\%)of teacher respondents have not decided on the issue. Thus, it is conclude the degree to which shared vision, mission, objective and goals high to improve for student achievement.

Item 2 of table 4, respondents were requested to rate the degree to which school management commitment is high for students achievement, 5(35.5\%) of principal agreed on school leaders commitment is high for student achievement, 4(28.5\%) of them were disagree,5(35.7\%) of principal respondents not decided,28(33.7\%)of teacher respondents agreed on school leaders commitment is high for student achievement,30(36.1\%)of teacher respondents disagreed on the issue, 25(30.1\%) of them have not decided on the issue. Thus, it is conclude the majority of respondents were school management commitment is low for student achievement.

Concerning item 3 table 4, 8(57.1\%) of principal respondents were agreed on consistency in implementation of school activities,3(21.4\%) of principal respondents strongly agreed and3(21.4\%)of principal respondents not decided,5(6\%)of teacher respondents were strongly agree on consistency in implementation of school activities,29(34.9\%)of teacher respondents were agreed on the issue, 28(33.7\%)of them disagreed,21(25.3\%)of teacher respondents have not decided on the issue.

Item 4 table $4,4(28.5 \%)$ of principal respondents were agreed on high mobilization of community for SIP support,7(50\%)of principal disagreed and 3(21.4\%)of principal respondents not decided,10(12\%)of teacher respondents strongly agree on high mobilization of community for School improvement program support,20(24\%)of teacher respondents were agreed,20(24\%)of teacher respondents disagreed on the issue 10(12\%)of teacher respondents strongly disagree and 23(27.7\%)of teacher respondents have not decided. Regarding item 5 of table $4,5(35.7 \%)$ of principal respondents have agreed on school has created effective regular communication with all stake holders,3(21.4\%)of principal disagreed on communication 
created with stakeholders,6(42.8\%) of school principals have not decided.6(7.2\%)of teacher respondents strongly agree on school has created effective regular communication with all stake holders, $19(22.8 \%)$ of teacher respondents were agreed on the issue,36(43.3\%) of teacher respondents were disagreed while 22(26.5\%) of teacher respondents have not decided on the issue. Thus, it is conclude that the majority of respondents were low regular communication with all stake holders.

Supervision is one of the mechanisms to check whether the teaching learning process goes properly. And teachers need to be given constructive feedback. As shown in the table regarding supervision of class rooms, $4(28.5 \%)$ of principal respondents agreed, $6(42.8 \%)$ of them disagreed, $4(28.5 \%)$ of school principal not decided on the statements, $21(25.3 \%)$ of teacher respondents agreed on the statements,9(10.8\%)of them are strongly disagree,27(32.5\%)of them disagreed on the statements while 26(31.3\%)of teacher respondents have not decided on the issue.

Item 7 of table $4,11(78.5 \%)$ of principal respondents were agreed on continuous follow up, and support of student learning, $3(21.4 \%)$ of school leaders respondents disagreed on the issue, $8(9.6 \%)$ of teacher respondents strongly agree on continuous follow up of student learning,38(45.7\%)of teacher respondents were agreed on the statement,10(12\%)of teacher respondents were disagreed on the issue,27(32.5\%) of teacher respondent have not decided on the issue whereas 10(12\%)of teacher respondents strongly agree on continuous support of student learning,43(51.8\%)of them agreed on the issue,10(12\%)of teacher respondents were disagreed,20(24\%) of teacher respondents have not decided on the issue. Thus, it is concluding that large number of school leaders and teachers indication of doing continuous follow up, and support of student learning.

\section{Community participation Domain}

As to Hopking (1994:126) in effective schools, there is evidence that success is associated with involvement that extends beyond the teaching staff. There is appositive benefit for students, including improved academic achievement, enhanced academic performance, fewer discipline problems, higher staff morale and use of resources. Parent's involvement in schools is therefore central to high quality of education.

Table-5: Responses of principals and teachers on Community participation Domain

\begin{tabular}{|l|l|l|l|l|l|}
\hline \multirow{3}{*}{ Items } & \multicolumn{5}{|c|}{ Respondents } \\
\cline { 2 - 6 } & Principals & \multicolumn{4}{l|}{ Teachers } \\
\cline { 2 - 6 } & & No & $\%$ & No & $\%$ \\
\hline \multirow{3}{*}{ PTA members participate in the SIP. } & StronglyDisagree & - & - & 15 & 18 \\
\cline { 2 - 6 } & Disagree & 6 & 42.8 & 27 & 32.5 \\
\cline { 2 - 6 } & Undecided & 4 & 28.5 & 15 & 18 \\
\cline { 2 - 6 } & Agree & 4 & 28.5 & 26 & 31.3 \\
\cline { 2 - 6 } & Strongly Agree & - & - & - & - \\
\hline \multirow{3}{*}{$\begin{array}{l}\text { Parents' comments about their children's } \\
\text { learning. }\end{array}$} & Strongly Disagree & - & - & 8 & 9.6 \\
\cline { 2 - 6 } & Disagree & 6 & 42.8 & 36 & 43.3 \\
\cline { 2 - 6 } & Undecided & 4 & 28.5 & 14 & 16.8 \\
\hline
\end{tabular}




\begin{tabular}{|c|c|c|c|c|c|}
\hline & Agree & 4 & 28.5 & 16 & 19.2 \\
\hline & Strong Agree & & - & 9 & 10.8 \\
\hline \multirow{5}{*}{$\begin{array}{l}\text { Stakeholders involvement in school } \\
\text { decision making on school activities. }\end{array}$} & Strongly Disagree & - & - & 5 & 6 \\
\hline & Disagree & 3 & 21.4 & 36 & 43.3 \\
\hline & Undecided & 6 & 42.8 & 14 & 16.8 \\
\hline & Agree & 5 & 35.7 & 23 & 27.7 \\
\hline & Strong Agree & - & - & 5 & 6 \\
\hline \multirow{5}{*}{$\begin{array}{l}\text { Teachers communicate parents about } \\
\text { students' academic progress regularly }\end{array}$} & Strongly Disagree & - & - & 9 & 10.8 \\
\hline & Disagree & 6 & 42.8 & 35 & 42.1 \\
\hline & Undecided & 4 & 28.5 & 19 & 22.9 \\
\hline & Agree & 4 & 28.5 & 17 & 20.4 \\
\hline & Strong Agree & - & - & 3 & 3.6 \\
\hline \multirow{5}{*}{$\begin{array}{l}\text { Parents and community members have } \\
\text { been involved in SIP } \\
\text { Implementation planning }\end{array}$} & Strongly Disagree & - & - & 16 & 19.2 \\
\hline & Disagree & 4 & 28.5 & 38 & 45.7 \\
\hline & Undecided & 6 & 42.8 & 15 & 18 \\
\hline & Agree & 4 & 28.5 & 14 & 16.8 \\
\hline & Strong Agree & - & - & - & - \\
\hline
\end{tabular}

Strongly agree $=5$, Agree $=4$, undecided $=3$, Disagree $=2$, strongly disagree $=1$

Item 1 of table 5, respondents were requested to rate the degree to which PTA members actively participated in the school improvement management, 4 (28.5\%) of principal respondents agreed on the issue,6(42.8\%)of principal respondents disagreed, 4(25.8\%)of principal respondents not decided,26(31.3\%)of teacher respondents agreed,15(18\%)of teacher respondents strongly agree,27(32.5\%) of teacher respondent disagreed while15(18\%)of teacher respondents not decided on the issue. Thus, it is conclude the degree to which parents as PTA members were not activities participation in the school improvement management.

Item 2 of table 5, 4(28.8\%) of principal respondents were agreed on parents' comments about their children's learning, 6(42.8\%) of principal respondents disagreed on the issue, $4(28.5 \%)$ of principal respondents not decided,9(10.8\%)of teacher respondents strongly agree on parents' comments about their children's learning,16(19.2\%)of teacher respondents agreed,8(9.6\%)of them strongly disagree,36(43.3\%)of teacher respondents disagree while $14(16.8 \%)$ of teacher respondents not decided on the issue.

Concerning item 3 table 5, 5(35.7\%) of principal respondents were agreed on stake holders involvement in school decision making on school activities, 3(21.4\%) of principal respondents disagreed and 6(42.8\%) of principal respondents not decided,5(6\%)of teacher respondents strongly agree on the issue,23(27.7\%)of teacher respondents agreed,5(6\%)of teacher respondents strongly agree,36(43.3\%)of teacher respondents disagreed while $14(16.8 \%)$ of teacher respondents not decided on the issue. The data obtained from interviews and document reviewed also supports teachers response, that there were no much efforts from school management to increase stake holder's participation in decision making process of the school in the study area. Therefore, it can conclude that stake holders are involved in decision making on their children and the school issues in collaboration with leaders and principal were unsatisfactory in the study area. This contradicts the result of Fullan (2000) that 
principal who are committed to share decision making saw shared decision making as one part of large package of reform.

Item 4 table 5, 6(42.8\%) of principal respondents were disagreed on teachers communicate parents about students' academic progress regularly, 4(28.5\%) of principal agreed and $4(28.5 \%)$ of principal respondents not decided,3(3.6\%)of teacher respondents strongly agree,17(20.4\%)of teacher respondents were agreed on the issue,9(10.8\%)of teacher respondents strongly disagree,35(42.1\%)of teacher respondents disagreed while19(22.2\%)of teacher respondents not decided on the issue.

Regarding item 5 of table 5,4 (28.5\%) of principal respondents have agreed on parents and community members have been involved in school involvement program implementation planning,4(28.8\%) of principals disagreed on the issue,6(42.8\%) of school principals have not decided,14(16.8\%)of teacher respondents were agreed on parents and community members have been involved in school involvement program implementation planning,16(19.8\%)of teacher respondents strongly disagree,38(45.7\%)of teacher respondents disagreed while $15(18 \%)$ of teacher respondents not decided on the issue.

Therefore, concerning the limited participation of parents and community in schools, the researcher concurs with Mulford (2003) who argues that there is a new kind of partnership in schools, in which both the school and the community contribute directly to the strengthening and development of each other.

\section{Awareness of stake holders on SIP}

Table-6: awareness of stake holders on SIP

\begin{tabular}{|c|c|c|c|c|c|c|}
\hline \multirow[t]{3}{*}{ No } & \multirow[t]{3}{*}{ Items } & \multicolumn{5}{|c|}{ Respondents } \\
\hline & & \multicolumn{3}{|l|}{ Principals } & \multicolumn{2}{|c|}{ Teachers } \\
\hline & & & No & $\%$ & No & $\%$ \\
\hline \multirow[t]{5}{*}{1} & \multirow{5}{*}{$\begin{array}{l}\text { Students have awareness on the SIP } \\
\text { implementation. }\end{array}$} & Strongly Disagree & - & - & 14 & 16.8 \\
\hline & & Disagree & 4 & 28.5 & 32 & 38.5 \\
\hline & & Undecided & 4 & 28.5 & 18 & 21.6 \\
\hline & & Agree & 6 & 42.8 & 19 & 22.8 \\
\hline & & Strongly Agree & - & - & - & - \\
\hline \multirow[t]{5}{*}{2} & \multirow{5}{*}{$\begin{array}{lrr}\text { The school principals } & \text { have } \\
\text { awareness on preparing } & \text { SIP } \\
\text { implementation strategic plan. } & \end{array}$} & Strongly Disagree & - & - & - & - \\
\hline & & Disagree & - & - & 11 & 13.2 \\
\hline & & Undecided & 3 & 21.4 & 17 & 20.4 \\
\hline & & Agree & 8 & 57.1 & 37 & 44.5 \\
\hline & & Strongly Agree & 3 & 21.4 & 18 & 21.6 \\
\hline \multirow[t]{5}{*}{3} & \multirow{5}{*}{$\begin{array}{l}\text { Parents and community members } \\
\text { have awareness on SIP } \\
\text { implementation }\end{array}$} & Strong Disagree & 3 & 21.4 & 13 & 15.6 \\
\hline & & Disagree & 6 & 42.8 & 39 & 46.9 \\
\hline & & Undecided & 1 & 7.1 & 16 & 19.2 \\
\hline & & Agree & 4 & 28.5 & 15 & 18 \\
\hline & & Strongly Agree & - & - & - & - \\
\hline \multirow[t]{4}{*}{4} & \multirow{4}{*}{$\begin{array}{l}\text { The school improvement } \\
\text { committee members have } \\
\text { awareness on SIP } \\
\text { Implementation }\end{array}$} & Strongly Disagree & - & - & 7 & 8.4 \\
\hline & & Disagree & 4 & 28.5 & 39 & 46.9 \\
\hline & & Undecided & 3 & 21.4 & 19 & 22.8 \\
\hline & & Agree & 7 & 50 & 18 & 21.6 \\
\hline
\end{tabular}




\begin{tabular}{|l|l|l|l|l|l|l|l|}
\hline & & Strongly Agree & - & - & - & - \\
\hline 5 & $\begin{array}{l}\text { The school supervisors } \\
\text { awareness } \\
\text { implementation }\end{array}$ & Sn school & Strong Disagree & - & - & - & - \\
\cline { 3 - 9 } & & Disagree & 2 & 14.2 & 19 & \\
\cline { 3 - 8 } & & Undecided & 1 & 7.1 & 12 & 14.4 \\
\cline { 3 - 8 } & & Agree & 8 & 57.1 & 44 & 53 \\
\cline { 3 - 7 } & & Strong Agree & 3 & 21.4 & 8 & 9.6 \\
\hline
\end{tabular}

Strongly agree $=5$, Agree $=4$ undecided $=3$, Disagree 2, strong disagree $=1$

As shown in Item 1 of table 6, respondents were requested whether or not students have awareness on the school improvement program implementation, 6(42.8\%) of principal respondents shows agreement on students have awareness on the school improvement program implementation, 4(28.5\%)of principal respondents disagreed, 4(28.5\%)of principal respondents not decided, $19(22.8 \%)$ of teacher respondents shows agreement on students have awareness on the school improvement program implementation,32(38.5\%)of them respondents disagreed, 14(16.8\%) of them strongly disagree,18(21,6\%) respondents not decided. Indicate the agreement of the large number of respondents with the issue. Therefore, it can be concluded that students in the study area have not awareness on the school improvement program implementation.

Item 2 of table $6,8(57.1 \%)$ of principal respondents were agreed on principals have awareness on preparing school improvement program implementation strategic plan, $3(21.4 \%)$ of principal respondents shows strong agreement on the issue, $3(21.4 \%)$ respondents not decided. $18(21.6 \%)$ of teacher respondents strongly agreed on principals have awareness on preparing school improvement program implementation strategic plan, $37(44.5 \%)$ of them respondents agree on the issue, 11(13.2\%)of them disagree, $17(20.4 \%)$ not decided. Therefore, it can be concluded that Principals in the study area have good awareness on the school improvement program implementation.

Concerning item 3 table $6,4(28.5 \%)$ of principal respondents were agreed on parents and community members have awareness on school improvement program implementation. $3(21.4 \%)$ of principal respondents strongly disagreed $6(42.8 \%)$ of principal respondents disagreed on the issue and $1(7.1 \%)$ of them not decided, $15(18 \%)$ of teacher respondents were agreed on parents and community members have awareness on school improvement program implementation, 13(15.6\%) of teacher respondents strongly disagreed on the issue, 39(46.9\%) of them disagree,16(19.2\%)of them not decided. From this concluded that parents and community have less awarded on SIP practices.

However, data obtained from respondents to interview item indicated that the majority parent and community at large have low awareness on the school improvement program implementation. In supporting this, Mesele (2011) suggested that enough awareness creations were not made for stakeholders in order to make them play active role in implementing the school improvement program at school level. Item 4 table 6, 7(50\%) of principal respondents were agreed on school improvement committee members have awareness on school improvement program implementation, $4(28.5 \%)$ of principal Disagreed and $3(21.4 \%)$ of principal respondents not decided.18 (21.6\%) of teacher respondents were agreed on school improvement committee members have awareness on school improvement program 
implementation, $7(8.4 \%)$ of them strongly disagree, $39(46.9 \%)$ of them disagree, $19(22.8 \%)$ not decided. From this we can concluded that the majority of respondents were the awareness of school improvement committee was low. In supporting this GEQIP community mobilization manuals of BGREB (2012) stated that Awareness creation for stake holders, financial and material support and practical training was not properly implemented.

Regarding item 5 of table 6,3(21.4\%) of principal respondents have strongly agreed on school supervisor awareness on school implementation, 8(57.1\%)of principals agreed on the issue.2(14.2\%) of school principals were disagreed,1(7.1\%)respondents have not decided $8(9.6 \%)$ of teacher respondents have strongly agreed on school supervisor awareness on school implementation, 44(53\%)of them agreed on the issue,19(22.8\%) of them disagreed,12(14.4\%) of teacher respondents have not decided. Therefore, it can be concluded that school supervisors have awareness on SIP implementation.

To sum, up the FGD respondents supporting the above analysis confirmed that no training was given practically to school improvement committee on school improvement implementation in sampled primary school.

\section{SIP Implementation Challenges}

This section deals with major a factor that affects implementation of SIP under the study area.

\section{Data obtained from principals and Teachers}

Table -7: Challenges of SIP Implementation

\begin{tabular}{|c|c|c|c|c|c|}
\hline \multirow{3}{*}{ Items } & \multicolumn{5}{|c|}{ Respondents } \\
\hline & \multicolumn{3}{|l|}{ Principals } & \multicolumn{2}{|c|}{ Teachers } \\
\hline & & No & $\%$ & No & $\%$ \\
\hline \multirow{5}{*}{$\begin{array}{l}\text { Poor technical support from Woreda } \\
\text { Education Office }\end{array}$} & Strong Disagree & - & - & - & - \\
\hline & Disagree & - & - & 12 & 14.4 \\
\hline & Undecided & 2 & 14.2 & 14 & 16.8 \\
\hline & Agree & 12 & 85.7 & 33 & 39.7 \\
\hline & Strong Agree & - & - & 22 & 26.5 \\
\hline \multirow{5}{*}{$\begin{array}{l}\text { Lack of training and awareness for } \\
\text { stakeholders to participate in SIP }\end{array}$} & Strong Disagree & - & - & - & - \\
\hline & Disagree & 1 & 7.1 & - & - \\
\hline & Undecided & - & - & 11 & 13.2 \\
\hline & Agree & - & - & 42 & 50.6 \\
\hline & Strong Agree & 13 & 92.9 & 20 & 24 \\
\hline \multirow{5}{*}{$\begin{array}{l}\text { Inadequate materials and financial } \\
\text { resource in the schools }\end{array}$} & Strong Disagree & - & - & 2 & 2.4 \\
\hline & Disagree & - & - & 11 & 13.2 \\
\hline & Undecided & 2 & 14.2 & 13 & 15.6 \\
\hline & Agree & 12 & 85.8 & 32 & 38.5 \\
\hline & Strong Agree & 11 & 13.2 & - & - \\
\hline \multirow{6}{*}{$\begin{array}{l}\text { Lack of qualified principals in } \\
\text { educational leadership }\end{array}$} & Strong Disagree & 2 & 14.2 & 14 & 16.8 \\
\hline & Disagree & 3 & 21.5 & 16 & 19.2 \\
\hline & Undecided & - & - & 11 & 13.2 \\
\hline & Agree & 9 & 64.2 & 42 & 50.6 \\
\hline & Strong Agree & 2 & 14.2 & 14 & 16.8 \\
\hline & Strong Disagree & - & - & 2 & 2.4 \\
\hline
\end{tabular}




\begin{tabular}{|c|c|c|c|c|c|}
\hline \multirow{4}{*}{$\begin{array}{l}\text { There is difficulties to change the } \\
\text { existing school culture }\end{array}$} & Disagree & - & - & 8 & 13.6 \\
\hline & Undecided & 5 & 35.7 & 10 & 12 \\
\hline & Agree & 6 & 42.8 & 44 & 53 \\
\hline & Strong Agree & 3 & 21.4 & 19 & 22.8 \\
\hline \multirow{5}{*}{$\begin{array}{llll}\text { Local political leaders are less } \\
\text { committed to support SIP. }\end{array}$} & Strong Disagree & - & - & - & \\
\hline & Disagree & - & - & - & \\
\hline & Undecided & 2 & 14 & 14 & 16.8 \\
\hline & Agree & 12 & 86 & 27 & 32.4 \\
\hline & Strong Agree & - & - & 42 & 50.6 \\
\hline \multirow{5}{*}{$\begin{array}{l}\text { Poor collaboration among stake } \\
\text { holders and the school to plan SIP } \\
\text { implementation }\end{array}$} & Strong Disagree & - & - & - & \\
\hline & Disagree & - & - & 12 & 14.4 \\
\hline & Undecided & 3 & 21.4 & 18 & 21.6 \\
\hline & Agree & 8 & 57.1 & 33 & 39.7 \\
\hline & Strong Agree & 3 & 21.4 & 20 & 24 \\
\hline \multirow{5}{*}{$\begin{array}{l}\text { Lack of encouragement for effective } \\
\text { school key actors (teachers, school } \\
\text { leaders, parents and students). }\end{array}$} & Strong Disagree & - & - & - & \\
\hline & Disagree & - & - & 14 & 16.8 \\
\hline & Undecided & 3 & 21.4 & 12 & 14.4 \\
\hline & Agree & 11 & 78.5 & 42 & 50.6 \\
\hline & Strong Agree & - & - & 15 & 18 \\
\hline \multirow{5}{*}{$\begin{array}{l}\text { Poor practice of school leaders in } \\
\text { searching external fund to promote SIP }\end{array}$} & Strong Disagree & - & - & - & \\
\hline & Disagree & - & - & - & \\
\hline & Undecided & - & - & 10 & 12 \\
\hline & Agree & 10 & 71.4 & 50 & 60 \\
\hline & Strong Agree & 4 & 28.5 & 23 & 27.6 \\
\hline \multirow{5}{*}{$\begin{array}{l}\text { Absence of SIP Implementation plan in } \\
\text { the school }\end{array}$} & Strong Disagree & - & - & 3 & 3.6 \\
\hline & Disagree & 3 & 21.4 & 9 & 10.8 \\
\hline & Undecided & 5 & 35.7 & 12 & 14.4 \\
\hline & Agree & 4 & 28.5 & 38 & 45.7 \\
\hline & Strong Agree & 2 & 14.2 & 25 & 30 \\
\hline
\end{tabular}

Strongly agree $=5$ Agree $=4$, undecided $=3$, Disagree $=2$ strongly disagree $=1$

Item 1 of table 7, Concerning poor technical support from Woreda Education Office $12(85.7 \%)$ of male principal respondents agree, $2(14.2 \%)$ of them are undecided, $22(26.5 \%)$ of teacher respondents strongly agree on poor technical support from Woreda Education office, $33(339.7 \%)$ of them agreed on the statement, 12(14.4\%)of teacher respondents disagree, 14(16.8\%)of them are undecided. Therefore, it can be concluded that poor technical support from WEO is challenge that encountered SIP implementation in the study areas.

Concerning lack of training and awareness for stake holders to participate in SIP 13(92.9\%) of principal respondents strongly agree,1(7.1\%)of them are disagree, 20(24\%)of teacher respondents strongly agree, $42(50.6 \%)$ of them are agree, 11(13.2\%)not decided on the issue. Therefore, it can be concluded that lack of training and awareness of the stake holders to participate in SIP implementation is one of the challenge that encountered in the study area. Concerning inadequate material and financial resource in the school $12(85.8 \%)$ of principal respondents agree, 2(14.2\%) not decided on the issue, 26(31.3\%) of teacher respondents strongly agree, 32(38.5\%) of teacher respondents were agree, 2(2.4\%) strongly disagree, $11(13.2 \%)$ of them disagree,13(15.6\%) not decided on the issue. Therefore, it can be concluded that shortage of materials and financial resource were the challenges that encountered the implementation of SIP in the study area. 
In response to item 4 of table 7, 2(14\%)of principal respondents strongly agree on lack of qualified principals in educational leadership, 9(64.2\%)of them are agree,3(21.5\%)of them are disagreed on the issue,14(16.8\%) of teacher respondents strongly agree on lack of qualified principals in educational leadership,42(50.6\%)of them are agree,16(19.2\%)of them are disagreed on the issue,11(13.2\%)of them have not decided. The background information of principals in the study area indicated that, $8(57 \%)$ were diploma holders, $6(43 \%)$ were first degree holders in different field of education rather than in educational leadership, from this the researcher is interested to conclude that lack of qualified(trained)principals in educational leadership was one of the challenge that encountered the effective implementation of SIP in the study areas.

As it has been shown in item 5 of table 7, 3(21.4\%)of principal respondents strongly agree on the idea of difficulty to change school culture, 6(42.8\%)of them agree, 5(35.7\%) not decided, $19(22.8 \%)$ of teacher respondents strongly agree on the idea of difficulty to change school culture, $44(53 \%)$ of them agree, $8(9.6 \%)$ of them disagree, $2(2.4 \%)$ strongly disagree, $10(12 \%)$ not decided.

Item 6 of table $7,12(86 \%)$ of principal respondents agree on the idea of local political leaders are less committed to support SIP, 2(14.2\%) not decided on the statement, 42(50.6\%) of teacher strongly agree on the idea of local political leaders are less committed to support SIP, $27(32.5 \%)$ of them are agree, $14(18.8 \% \%)$ not decided on the statement. Therefore, it can be concluded that low commitment of local political leaders were one of the challenge that encountered SIP implementation in the study area

Item7 of table7 shows the idea of poor collaboration among stake holders and the school to plan SIP Implementation,3(21.4\%)of principal respondents strongly agree, 8(57.1\%)of them are agree, 3(21.4\%)undecided,20(24\%)of teacher respondents strongly agree,33(39.7\%)of them are agree,12(14.4\%)of them are disagree,18(21.6\%) of them not decided., Therefore, it can be concluded that poor collaboration among stake holders and the school to plan school improvement program implementation

Concerning lack of encouragement for effective school key actors,11(78.5\%) of principal respondents agree, 3(21.4\%) not decided, 15(18\%)of teacher respondents strongly agree on lack of encouragement for effective school key actors,42(50.6\%)of teacher respondents agreed,14(16.8\%)of them disagree,12(14.4\%) of teacher respondents not decided. Item 9 of table 7 shows, 4(28.5\%)of principal respondents strongly agree on the poor practice of school leaders in searching external fund to promote SIP,10(71.4\%)of them are agree on the issue, $23(27.7 \%)$ of teacher respondents strongly agree on the poor practice of school leaders in searching external fund to promote SIP,50(60.2\%)of them are agree on the issue, 10(12\%)not decided. Therefore, it can be concluded that poor practice of school leaders in searching external fund to promote school improvement program in the study area.

Concerning absence of school improvement program implementation plan in the school,2(14.2\%)of principal respondents strongly agree,4(28.5\%)of them agree,3(21.4\%)of them disagree,5(35.7\%) undecided on the issue. Whereas $25(30.1 \%)$ of teacher respondents 
strongly agree,38(45.7\%)of teacher respondents agree,9(10.8\%)of them disagree,3(3.6\%)of them strongly disagree,12(14.4\%) of teacher respondents not decided on the issue. Therefore, it can be concluded that absence of school improvement program implementation plan in the school in the study area.

\section{Analysis of Qualitative Data Obtained From Principals and Teachers}

\section{Teaching and Learning}

As qualitative data collected from principals and teachers suggested that the strengths of teaching and learning in respect to SIP Implementation are arrangement of tutorial for female and slow learners, increasing participation of students, student-centered teaching method and following continuous assessment. Besides, the participants also pointed out about the weakness of teaching and learning in respect to SIP Implementation. These are: lack of facilities likes science kits, computers, pedagogical centers, laboratories and internet access. Lack of quality of Education, lack of solving school problems and lack of stake holders' collaboration are also raised as other weaknesses.

In qualitative data response participants also raised the possible solutions expected. For instance, the government should have to play its own role to minimize lack of facilities like science kits, computers, and laboratories. The participants also forwarded that the teachers should have to conduct action research and solve the problem of schools. Principals, teachers and students should work in collaboration and ensure quality of education. The other concern of these participants is that the management be supposed to work with all stake holders for all activities in the school.

\section{Learning Environment}

Qualitative data collected from principals and teachers suggested that the strengths of learning Environment in respect to SIP Implementation, all students have equal chance for learning, student focus, student Empowerment. Besides, the participants also pointed out about the weakness of learning Environment in respect to SIP Implementation, lack of creating conducive environment, lack of health relationship among school community, lack of Pedagogical center, lack of access to standard toilet for female and male student, lack of library with sufficient reference book,

In qualitative data response participants also raised the possible solutions expected. For instance, Teachers should take their role in creating conducive environment, the school compound itself should be more attractive and School leaders create health relationship with school community, School Board, PTA and Woreda Education Office solving pedagogical center, toilet and library with recent reference book.

\section{Leadership and Managements}

Qualitative data collected from principals and teachers suggested that the strengths of leadership and management in respect to SIP implementation are preparation of planning, 
clear vision. Besides, the participants also pointed out the weakness of leadership and management in respect to SIP Implementation. These are weakness points are in the lack of giving attention to teaching and learning rather it gives more time for the need political party, lack of School management commitment, lack of regular meeting with all stake holders, lack of commitment, lack of preparing participant plan, Lack of technical work, In qualitative data response participants also raised the possible solutions expected. For instance, School principals should give due attention to teaching and learning rather than party need, School principals should regular communicated with all stake holders, Creating strong partnership with partner organization for financial, technical, material and other necessary support needed to raise quality of education.

\section{Community Participations}

Qualitative data collected from principals and teachers suggested that the strengths of community participation in respect to SIP Implementation are partnership with parents and careers, some relationships student send in school. Besides, the participants also pointed out about the weakness of community participation in respect to SIP Implementation. These are: lack of collaboration with school, lack of participation by financial, material and force, lack of follow up and support their student and lack of motivate student also other weakness

In qualitative data response participants also raised the possible solutions expected. For instance, Schools should work is collaboration with the community, Community participation is vital in teaching and learning process because without community participation the government cannot ensure the quality of education, Mobilization of the community by creating a wide range of awareness about the importance community participation in improving student's performance in particular in schools improvement in general.

\section{Factors that hinder effective implementation of SIP}

The analysis of the qualitative data collected from principals and teachers reveal that there is lack of financial resource and facilities, poor technical support from CRC Supervisor and Woreda Education Office, lack of qualified principals for the required position, lack of awareness on the SIP Implementation, lack of local political leaders to give attention about SIP Implementation, the training provide to stake holders is not adequate, lack of involvement of stake holders and collaboration are also raised as other challenge.

In qualitative data response participants also raised the possible solutions expected. For instance, allocating adequate financial resources to school and full filling school facilities, assigning committed supervisors and WEO officers who work for SIP implementation, assigning qualified principals who are committed to SIP, developing awareness of stake holders to participate in school improvement implementation, the government and political leaders have to give attention for SIP implementation and the quality of the training should be enhanced.

\section{The Woreda Education Office head and process owners were interviewed on the different aspects of SIP.}


One of the respondents about SIP said that:

I have taken training on SIP. The Office gives training opportunity for school community on issue related to SIP once in the year. Regarding awareness of stake holders, I believe that supervisor; Principals and teachers have adequate awareness on SIP but students and parent's inadequate awareness on school improvement program. Concerning office job performance follow up, monitor and supervise time to time additional by checklist. As far as proper utilization of school grant is concerned. I believe they are used by the schools for the intended purpose: the office has mechanism for controlling the schools. I believe that the community participation is also low. As far as the challenges faced during the implementation process, there is lack of commitment from all stake holders; also there is a lack of interest on the part of teachers. I suggested that all stake holders should work collaboration. (Source: Interviewee)

\section{The CRC Supervisors were interviewed on the different aspects of SIP}

One of the respondents about SIP said that in my cluster the implementation of SIP low. Because of there was lack of budget, lack of facility, lack of laboratory, lack of desk, lack of classroom and student ratio size. Regarding leadership and managements it was found out that there was imposition of politics in schools. Lack of giving attention to teaching and learning rather it gives more time for the need political party, lack of commitment, lack of making decision so, leadership and Management not play role with regard to SIP. With respect to make physical and social environment of class room and School conducive for learning I believe that the efforts have been exerted trained, man powers, regarding effort made to increase awareness of stake holders like monitoring and self-evaluation, training, work with collaboration are some of increase awareness of stake holders. As far as the utilization of school budget and school grant concerned I believes they were used by the schools for the intended purposes; the office has mechanism for controlling the schools. As far as the challenges faced during the implementation process, there was lack of commitment from all stake holders, lack of facility, and lack of interest on the part of teachers. I suggested that all stake holders should work jointly. (Source: Interviewee)

\section{Conclusion and Suggestion}

The results of the study reveal that there were many challenges that hinder effective implementation SIP in primary schools of Elu Gelan Woreda. Therefore, based on the findings of the study the following conclusions were drawn. The analysis of data concerning to teaching and learning domain indicated that there were poor conduct action research, unavailability of instructional media to motivate student, absence of laboratory, library, reference books, pedagogical center and computers. With respect to learning environment 
domain, there was a lack of healthy relationship among school community, lack of standard toilet for female and male student.

On the other hand, the study revealed that there were poor commitments of school management, poor instructional supervision, mobilization of community, irregular communication with stakeholders. The study also showed that most of the educational leaders were not qualified in an area of educational leadership. Concerning community involvement domain, there waspoor participation PTA in SIP implementation, poor participation in decision making, poor comment up on their student learning, lack of awareness students, parents, community and SIP committee on implementation of SIP and parent and community have been involved in SIP planning unsatisfactory.

In most of the schools there was shortage of budget for implementation of SIP, insufficient school facilities(desk, library, pedagogical center, laboratory, computer), inability of school improvement committee to play their role respectively were identified as the most major factors which affect the implementation of SIP. Therefore, based on the findings, it is possible to conclude the implementation of SIP has not done much as indicated in SIP frame work in the sample schools. Generally, primary schools of the study area were unsatisfactory in implementation of SIP.

The central focus of SIP was improving students' achievements. In order to improve academic achievements of students, therefore, the schools should implement SIP properly by making awareness creation for stake holders on collaborative planning to develop the accountability in all stake holders, to implement and improve the four domains of SIP and identifying challenges that affect the implementation of SIP. Therefore based on the findings and conclusion drawn the following recommendations are forwarded to be used by the practitioners:

1. In order to implement SIP in line with the framework, creating awareness and providing sufficient training for all stake holders (students, community, SIC and parents) by WoredaEducation Offices to carry out their responsibility to implement effectively SIP.

2. The study showed that to solve academic problem of students; utilization of laboratory, library, use of instructional media, conducting action research, would help to promote learners academic achievement. Therefore, school principals should be collaborate with WEO,to facilitate training, motivate encourage teachers for good practice.

3. The findings showed that there were insufficient school facilities to carry out SIP implementation. Therefore, Woreda Education Offices (WEO), Kebele and schools should full fill school facilities for success of SIP.

4. The findings showed that the involvement of stake holders in SIP implementation were not at the required level.So that school should make an effort to involve stake holders(teachers, students and parents)for the success of SIP.

5. The study indicates that community participation is unsatisfactory; this implies that school management practices less effort to enhance their participation in 
implementation of SIP. Therefore, community participation should get more attention for supporting implementation of SIP.

6. The findings showed that on the practice of SIP, poor collaboration among stake holders, shortage of facility, lack of financial, low awareness, lack of qualified school principals in educational management, low commitment of political leader, poor technical support from WEO and poor practices of school leaders in searching external fund were among factors that affect SIP. There for, the researcher recommended that all concerned bodies (school director, supervisor, PTA, Kebele School Board, stake holders and WEO) should give attention and minimized for those negatively.

\section{Conflict of Interest}

The authors declare no conflict of interest

\section{Funding}

The authors conducted this study at their own expense and were not funded by any institution/ university.

\section{Availability of Data and Material}

The data that support the findings of this study are available from the corresponding author, upon reasonable request.

\section{References}

ACT government (2004). School Improvement Framework Guidelines for Schools Improvement._Sydney: Education Youth and Family Service.

Adelman, L., \& Taylor, H. (2007). Festering school, family, and involvement; effective strategies for creating safer schools and communities. Washington: Hamilton Fish.

Adesina, S.(1990). Education management. Absiani Eng.4 ${ }^{\text {th }}$ Dimention publishing Co. LTD.

Aggarwal,J.C.(1996).Theory and Principles of Education: philosophical and sociological basis of Education(10 ${ }^{\text {th }}$ ed) New Delhi:Vicas puplishing pvt.Ltd.

Anees; M. (2001).Future Trends and Distance Education in Pakistan. Unpublished M.Phil Thesis, Allama Iqbalopen University, Islamabad.

Best and Kahan(2005). How Communities Build Stronger School Stories, Strategies and Promising Practices for Educating Every Child. New Delhi: McMillan.

BGREB (2012).General Education Quality Assurance package Community Mobilization Manual .Asosa (Unpublished Training Material).

Borg; W.R. and Gall; M.D.(1989). Educational research: An introduction of (5 ${ }^{\text {th }}$ Ed.).New York: Longman Publishers 
Burkett,H. (2006). SIP planning process. Washinington DC.

Coolican; H. (1992).Introduction to research methods and statistics in psychology $\left(2^{\text {nd }}\right.$ Ed.)London: Hodder and Hongthon

Davis, B and Ellison, L(1992'6) school development planning: Issue in school management, Harlow; Longman

Estyn (2001).Good practice in Leadership and Management of school.Ancholcourt:UK

Gallagher.K (2004).School improvement frame work for achievement high standard in student learning, innovations and best practice in ACT government wiscons in Lawrence Er/Baum. INC.

Harris, A.(2001).Building the Capacity for School Improvement: School leadership and Management. Final Report,21(3):261-270.

Harris,(2002)School improvement; what is it for school?London;Rutleadge/Flamer/

Hopkins, D. (1994). School Improvement in an Era of Change. Promotion Quality in SchoolLondon: Cassell. Hopkin.D.(2001).School Improvement for Real.Rouledge.Falmer.

Hopkins, D.(2002).Improving the Quality of Education for All. A Handbook of Staff Development of Activities( $2^{\text {nd }}$ Edition).London: David Fulton publishers Ltd.

Hussen, T. and Postlwaite, N. (1994).The International Encyclopedia of Education (2nd Ed). Oxford: Elsevier science Ltd.

Marzano, R. (2003). What works in schools: Translating Research in to Action.Alexandria,.VA: ASCD

Mesele, S.(2011).Current practices and challenges of School Improvement program In some Selected primary school of Sodo Zura Woreda in Wolyita Zone Senior Essay Addis Ababa University (Unpublished).

MoE (1994).Education and Training Policy: Federal Democratic Republic Government of Ethiopia.( $1^{\text {st }}$ Edition).Addis Ababa. St.George Printing Press

MoE (1998).Education Sector Development Program: (ESDP-I) Implementation Manual. Addis Ababa: MoE

MoE (2002).The Education and Training Policy and its Implementation: Addis Ababa.

MoE (2005).Education Sector Development Program,(ESDP-III).

MoE (2006).Education Sector Development Program(ESDP-II) (1995 E.C) 1997 E.C

Joint Review Mission (10th -28th Oct. 2005 G.C) Final Report

MoE(2007a). General Education Quality Assurance Package: Addis Ababa.

MoE (2007).School Improvement Program Fram work. Addis Ababa.

MoE(2010). School Improvement Program Guidelines, Final Draft: Addis Ababa: MoE.

$\operatorname{MoE}(2011)$. Guidline for the Implementation of the school improvement program. Addis

Ababa: MoE(Reviesed).

Mugenda;O.M.and Mugenda; A.G.(1999).Research methods: Qualitative and quantitative approaches. Nainobi:ACTS Press.

Mugenda; O.M. and Mugenda; A.G. (2003).Research m methods: qualitative and quantitative approaches. Nairobi: act press.

Munene; C.k. and Ogula; P.(1999). A handbook on educational assessment and evaluation: Nairobi: New Kemit Publishers. 
Morgan, J.S (2006) What community participation in schooling means: Insights from Southern Ethiopia Harvard Education review,76(3)

Plan-International.(2004).The School Improvement Program. Retrieved on 15 Sept, 2009 from http//www.plan-international.org.

Plan international Sudan (2006).End term evaluation of school improvement project. Khartoum.

Reynolds, D., Bollen, R., Creemers, B. P., Hopkins, D., \& Stoll, L. (1996). Making good schools: Linking school effectiveness and school improvement. Psychology Press.

Olsen,G.E.(1954). School and Community( $2^{\text {nd }}$ Ed):California: Prentice Hall,Inc.

Simpkins, K. (2009). Quality education and the essential need school improvement. Unpublished Guideline Paper. Addis Ababa: Ministry of Education

Stoll, L.and Fink, D. (1996).Changing Our Schools: Linking School Effectiveness and School Improvement. Philadelphia: Open University press.

UNICEF.(2000).Defining Quality in Education. A paper presented by UNICE at the Meeting of the International working Group on Education Florence, Italy

June 2000 J.T., Marzano, R.J. \& McNulty, B. (2004). Leadership That Sparks Learning.

UNICEF (2009).Child-Friendly Schools: Ethiopia Case Study. Addis Ababa, Ethiopia Waters

UNICEF (2010).Child-Friendly Schools: Ethiopia Case Study. Addis Ababa, Ethiopia. 